\title{
The role of business incubators in creating sustainable small and medium enterprises
}

\begin{tabular}{|c|c|}
\hline \multicolumn{2}{|l|}{$\begin{array}{l}\text { Authors: } \\
\text { Lia M.M. Hewit } \\
\text { Lodewikus J. Ja } \\
\text { Rensburg }^{2} \text { (D) }\end{array}$} \\
\hline \multicolumn{2}{|c|}{$\begin{array}{l}\text { Affiliations: } \\
{ }^{1} \text { Department of Industrial } \\
\text { Psychology and People } \\
\text { Management, College of } \\
\text { Business and Economics, } \\
\text { University of Johannesburg, } \\
\text { Johannesburg, South Africa }\end{array}$} \\
\hline \multicolumn{2}{|c|}{$\begin{array}{l}{ }^{2} \text { Department of Business } \\
\text { Management, College of } \\
\text { Business and Economics, } \\
\text { University of Johannesburg, } \\
\text { Johannesburg, South Africa }\end{array}$} \\
\hline \multicolumn{2}{|c|}{$\begin{array}{l}\text { Corresponding author: } \\
\text { Lia Hewitt, } \\
\text { mhewitt@uj.ac.za }\end{array}$} \\
\hline \multicolumn{2}{|c|}{$\begin{array}{l}\text { Dates: } \\
\text { Received: } 01 \text { Nov. } 2019 \\
\text { Accepted: } 03 \text { June } 2020 \\
\text { Published: } 25 \text { Aug. } 2020\end{array}$} \\
\hline \multicolumn{2}{|c|}{$\begin{array}{l}\text { How to cite this article: } \\
\text { Hewitt, L.M.M. \& Janse van } \\
\text { Rensburg, L.J., 2020, 'The } \\
\text { role of business incubators in } \\
\text { creating sustainable small } \\
\text { and medium enterprises', } \\
\text { Southern African Journal of } \\
\text { Entrepreneurship and Small } \\
\text { Business Management 12(1), } \\
\text { a295. https://doi.org/ } \\
\text { 10.4102/sajesbm.v12i1.295 }\end{array}$} \\
\hline \multicolumn{2}{|c|}{$\begin{array}{l}\text { Copyright: } \\
\text { (C) } 2020 \text {. The Authors. } \\
\text { Licensee: AOSIS. This work } \\
\text { is licensed under the } \\
\text { Creative Commons } \\
\text { Attribution License. }\end{array}$} \\
\hline \multicolumn{2}{|l|}{ Read online: } \\
\hline 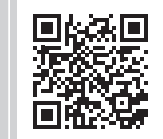 & $\begin{array}{l}\text { Scan this QR } \\
\text { code with your } \\
\text { smart phone or } \\
\text { mobile device } \\
\text { to read online. }\end{array}$ \\
\hline
\end{tabular}

Background: Despite the prevalence of business incubators as platforms through which new ventures can be technically and financially supported, there is controversy on the extent to which a one-size-fits-all approach to business incubator support can be applied to all emerging or existing small and medium enterprises (SMEs).

Aim: To explore the value addition and role of business incubators to assist entrepreneurs to grow their businesses to enable them to become entrepreneurial leaders.

Setting: State of SMEs; Business incubators; the development of entrepreneurs in South Africa. Method: A literature survey regarding the nature of business incubators was conducted, making use of a convenience sample comprising a pre-published list of 58 business incubators.

Results: Business incubators see themselves in a position of strength and are not in a true partnership with the incubatee. Most business incubators only support Broad Based Black Economic Empowerment candidates, ignoring the needs and value-add of a diverse SME population. Findings highlighted the conflicting information about the state of SMEs in South Africa, thereby calling for policies to clearly and uniformly report reliable statistics on the status of SMEs to enable more focussed support for SMEs.

Conclusions: Business incubators must clearly conceptualise their own business operating model and articulate their value-add to prospective emerging entrepreneurs. Post COVID-19 it is essential to fast tract the sustainability of SMEs and role clarification and differentiating are two important factors that need to be taken into consideration by both business incubators and entrepreneurs to ensure focussed support and allocation of public and private funding.

Keywords: business incubators; emerging ventures; business incubator criteria; resources; small and medium enterprises.

\section{Introduction}

Business incubators is a concept that gained its origin in the city of Batavia, USA, in 1959, when Joseph L. Mancuso launched the Batavia Industrial Center (Lewis 2001). The focus, primarily, of business incubators should be on providing support services to start-ups, to overcome typical business challenges such as financial knowledge, rental space, human resources, access to markets and skills development. They should not be confused with large industrial parks. It might be that some large industrial parks house business incubators. The use of business incubators has since spread all over the world and is used extensively in emerging economies to support emerging and upscale survivalist small businesses (Rathore \& Agrawal 2020).

South Africa (SA) is the second largest economy, after Nigeria, in Africa. However, its gross domestic product (GDP) per capita will be less than the rest of the world's emerging markets within 3 years.

The difference between rich and poor in SA is the biggest in the world and in fact has increased since 1994, after the takeover of the democratic African National Congress (ANC) (World Bank Report 2018). Post-apartheid, Broad Based Black Economic Empowerment (BBB-EE) was one strategic policy initiative implemented to redress the inequality between rich and poor. However, Saba (2018) reports that the BBB-EE Commission indicates that between 2015 and 2017 the number of black business owners has declined from $33.5 \%$ to $27.8 \%$. The apparent failure of BBB-EE can be ascribed to corruption, lack of investment opportunities, policy uncertainty (property rights for example), ineffective policies and the implementation thereof (South African Market Insights [MI] 2019). If SA fails to get the economy going, poverty, overall wealth, education, growth and 
development for all the people of SA are at risk. Ramaphosa, the current South African president, re-emphasised that small and medium enterprises (SMEs) must sustain the South African economy as is the case in other countries. Strategies must be aligned to meet the target set in the National Development Plan (2030), which envisaged that $90 \%$ of all jobs in SA must come from the SME sector.

One of the strategic instruments to assist and nurture SMEs is business incubators. The purpose of a business incubator is to reduce the chances of failure of start-ups and to provide them with support as well as to nurture them up to a stage where they can become independent businesses. Recently, a list of 58 South African business incubators was published (Crampton 2019). This calls for a critical review of what an evidence-based business incubator consists of, their role and what type of services they offer to SMEs.

\section{Research problem and question}

Hausberg and Korreck (2018) conducted a detailed and systematic review on business incubator literature.

They observed that some papers started to summarise the field, but that there are still questions that remain unanswered. The authors noticed that different types of business incubators - (1) corporate and (2) public - and different names for business incubators started to emerge. Various descriptive definitions evolved, from broad to very specialised, and that these definitions do not distinguish between corporate and public-funded business incubators. In line with international trends, SA also adopted the concept of business incubators to counteract the mortality rate of start-ups (Masutha \& Rogerson 2014). The incubator landscape in SA is characterised by public and corporate funding, but this raises issues regarding their relationship with their incubatees and their sponsors, which has different interest. Based on the above, the following research question is formulated.

To what extent do business incubators (public and private) in SA meet the needs of their incubatees and do they fulfil their intended role?

\section{Research philosophy and design}

The researchers hold an epistemological constructivism stance, supported by an interpretivism theoretical perspective (Gray 2014). As the focus of this article is on the role of business incubators and to what extent they serve the needs of prospective incubatees, the researchers approached these from three areas: (1) the state of SMEs in SA, as the state of SMEs would support the demand and/or need of business incubators and justify the investment required by public and private sectors; (2) recent literature on business incubators; and (3) a practical analysis of the services offered by 58 business incubators to SMEs in SA and site visits to three prominent business incubators to infer to what extent the needs and services coincide. An inductive approach was followed to construct meaning and to draw inferences.
A convenience sampling approach was followed as Crampton (2019) published a list of 58 business incubators offering their services to potential incubatees in SA. The researchers conducted an extensive analysis of their websites of all 58 business incubators, following up on the services they offer and whom their services were offered to. The researchers further conducted site visits to three well-known business incubators in the Gauteng province to observe and to understand the social reality of business incubators and incubatees that will allow them to gain new insights on the role that the (public or private) business incubators play in SA and to draw conclusions on the extent to which these business incubators fulfil their role to serve the needs of incubatees.

\section{Discussions}

One of the allotting factors is that when a researcher attempts to build a picture of the current state of SMEs in SA, many conflicting and contradicting statements and reports are found.

\section{The state and failures of small and medium enterprises in South Africa}

Ravi Govender, Head of Small Enterprises at Standard Bank (2018), stated that the alarming rate at which SMEs either seized to exist or fail ( $50 \%$ within the first year) is a matter of grave concern and can be attributed to various factors such as (1) skills, lack of experience and resources because the SME was in the first place started out of necessity; (2) failure to distinguish between own and business accounts; (3) poor cash flow; and (4) access to finance.

A different SME failure statistic is provided by the CEO Eustace Mashimbye (cited in Crampton 2019), who claims that $70 \%-80 \%$ of SMEs do not survive their first year. The Department of Trade and Industry (DTI 2014) puts this figure at $80 \%$ - SMEs failed within their first 5 years. The Department of Small Business 2018/2019 Annual Performance Plan revealed that 2015 figures from Statistics SA show a decline in SME employment. Monitoring government spending on SMEs (with a failure rate of 70\%), the impact made could not be seen.

The Small Enterprise Development Agency (SEDA) in SA reported that there were $2.25 \mathrm{~m}$ SMEs in SA (SEDA 2017) and $2.56 \mathrm{~m}$ in 2018 (SEDA 2018). An increase thus was 13.6\%. Small Enterprise Development Agency Gauteng provincial manager Colin Leshou (2018) reported that, in SA, SMEs increased from $1.6 \mathrm{~m}$ in 2000 to $5.6 \mathrm{~m}$ in 2010. Of these SMEs, $3.3 \mathrm{~m}$ were classified as survivalist, $1.7 \mathrm{~m}$ as micro-enterprises and 554000 as small enterprises. What is concerning is that Leshou shared 2010 statistics with no indication of what the current state is of SMEs in SA.

Analysing and comparing two key fact sheets from 2017 and 2019 by Fotoyi and Levin (2019), Makgetla, Philip and Fotoyi (2019) of the Trade \& Industrial Policy Strategies, an independent non-profit economic research institution on 
'The state of small business in $\mathrm{SA}^{\prime}$, reveal further confusing trends. It is reported by Fotoyi and Levin's (2019) key fact sheet on the 'State of small businesses in SA' that there were $1.5 \mathrm{~m}$ informal businesses in SA, unchanged from 2008, and 670000 formal business, down from 707000 in 2008 . Employment in the formal SME sector was reported at $5.8 \mathrm{~m}$ against $3.6 \mathrm{~m}$ in large formal businesses. Thus, SMEs were the major employers at the time. Of the small and microenterprises, $51 \%$ were owned by white people, down from $62 \%$ in 2002.

Makgetla et al.'s (2019) key fact sheet on the 'State of small business in SA' during the period, 2017, indicates that the number of informal small businesses was $1.5 \mathrm{~m}$ and increased from $1.3 \mathrm{~m}$ since 2010 .

The number of formal small businesses in 2017 was 640000 , an increase of 50000 from 2010. Yet, in 2015 it was reported that there were 707000 SMEs in 2008, and this declined to 670000 in 2015. The claim in 2019 was made that the total number of SMEs grew by 50000 from 2010 (590 000 SMEs), which is less than what is reported to be the total. How do the authors explain the 'missing' numbers of SMEs? They further indicate that $50 \%$ of formal jobs is located within the small business environment and that the estimated share of SA GDP is around $25 \%$. White ownership has showed a continuous decline in SME participation to $45 \%$.

Recent research conducted by the Small Business Institute (SBI) (SBI 2018/2020) claims that the 'alarming truth' is in fact that there is only approximately a quarter of a million (250 000) formal SMEs in SA. This is clearly very different from various other reports. Small Business Institute research $(2018 / 9)$ further claims that $98.5 \%$ of the SA economy is made up of SMEs, but that they only provide $28 \%$ of the jobs. More than $56 \%$ of jobs are created by the 1000 largest firms in SA, including the government. The DTI (2014:15) claims that SMEs account for $70 \%$ of national employment. This shows a sharp decline in SME employment since 2014. The impact of COVID-19 on the sustainability of SMEs is devastating, A desktop search quickly showed that all is in agreement to this affect, however hesitant to make an estimation of the number of SMEs that have already or will shortly close their doors.

One of the more recent Quarterly Financial Statistics (March 2019) reports that the updates on formal business sector turnover indicated that of the R2.39 trillion in turnover, small businesses contributed 29\%, and medium-size businesses contributed $10 \%$. A notable decline is reflected in various sectors such as community, social and business services with construction showing the most notable decline of $40 \%$ (Q1:2015) to 26\% (Q1:2019) (Quarterly Financial Statistics [March 2019]). However, three industries -business services, trade and community, and social and personal services - are still dominated by SME presence (contributes a quarter of the overall turnover) and include enterprises such as hairdressers, dry-cleaning services and veterinary clinics (community, social and personal services); lawyers and estate agents (business services); and corner cafés (trade) (Quarterly Financial Statistics, March 2019).

The Organisation for Economic Co-operation and Development (OECD) has 34 member countries and it reports that in these countries SMEs represent 95\% of enterprises and employ $60 \%-70 \%$ of their respective populations. Furthermore, these SMEs contribute about $60 \%$ to their countries' GDP. According to the research published by SBI, this makes SA an international outlier.

Hewitt and Janse Van Rensburg (2018) postulate that SMEs fail because of the inability of the entrepreneur to deal with associated contextual business complexity requirements at various stages of the business. They have developed a model (based on research evidence, practical experience and years of entrepreneurship training) - an Entrepreneurial Leadership Levels and Its Associated Complexities (ELLAC) Model demonstrating what entrepreneurs should have in place at each level before progressing to the next level. Levels are clearly defined and form a solid foundation to ensure business sustainability. It is argued that the current COVID-19 pandemic will have a deteriorating effect on many SMEs in SA. This is ascribed to the weaknesses that existed in the SME before the pandemic. The business eventually dies, terminates or the 'entrepreneur' deviates to a new product or service, a 'try again' approach.

\section{Definition of small and medium enterprises}

The SBI (2018) reviewed more than 70 laws, regulations and strategic policy documents relating to SMEs, realising that there is no standard definition of what is considered as a small, medium and micro-enterprise across SA's local government documents. Institutions' failure to clearly define what is meant by a small and medium enterprise contributes to the failure to implement good policies. As recent as 15 March 2019, the then Minister of Small Business Development approved the amendment of the national definition of small enterprises in SA (Government Gazette, March 2019:110:42304). The amendment further abolishes the term 'very small enterprises', as it is not used in international practices and will be absorbed by the term small enterprise. Scanning through other policies and acts that must be read in conjunction with the act, it supports the research conducted by SBI that none of the definitions speaks to each other as they differ across policies and government documents. The research conducted by SBI clearly states that without reliable data on what constitutes SMEs, how many are there and what their real contribution is with respect to the GDP, SA will not be able to achieve its strategic objectives despite good intentions and policies. Removing 'micro' might also be capitalised on by government institutions and other stakeholders who can pitch SME numbers now at $1.5 \mathrm{~m}$ and higher.

This figure will obscure the real negative growth or state of SMEs in SA. 


\section{Business incubator models}

The most recent comprehensive literature review by means of a bibliometric and co-citation analysis was conducted by Hausberg and Korrect (2018), stretching back to more than a decade. Although their work focussed on corporate business incubators and their performance, it showed that business incubators have evolved into complex business-development organisations with a range of business models and that the rise of private business incubators is significant in large corporations. Their study builds on the work done by Hackett and Dills (2004), who conducted a comprehensive systematic literature review on business incubators.

Hackett and Dills (2004) included 38 studies in their review and concluded that incubators serve as a mechanism for new venture creations, provide legitimacy and networks, and increase community support. Furthermore, it provides a platform for building a client base and serves as a sociopolitical game of creating an environment and perception of reduced risk and an increase in security within a given physical space.

Incubatee selection is a predictable and a controllable process of 'weak-but promising' firms.

Exploring the characteristic of business incubators, it became evident that we were still required to visit earlier publications such as Campell, Kendrick and Samuelson (1985), who emphasised four value-adds that a business incubator must possess: (1) an incubator must be able to diagnose business needs; (2) there must be a selection and monitoring of the services provided to these firms; (3) investment of capital and the access to the working; and (4) network of the incubator. The overall focus here is on the incubator process.

Ryzhonkov (2013) criticises this model and points out that the following shortcomings are evident in this model such as a clear explanation of the incubation process; the viability of the entrepreneurs and their competencies; a failure to link the external environment to the entrepreneur; and no clear selection process for the incubatees or the potential business they intent to support. In his conclusion he recognises the value-adds that incubators must provide to their incubatees. Merrifield (1987) studied the model as proposed by Campell et al. (1985) and added proposed selection criteria to select a prospective incubatee by means of three questions: is this a good business? Does the incubator have the resources and knowledge to support the new business and what is the best marketing penetration approach for this firm to enter the market? What is defined as a 'good business' is unclear?

Smilor's model (1987) used Campell et al.'s (1985) model to build on. He moved to a more structured approach, opposed to an incubator system, but highlighted the value-add that business incubators can provide to entrepreneurs, in the form of credibility development, shortening of the learning curve, faster trouble shooting and access to networks.
Ryzhonkov (2013) conducted an extensive and very comprehensive analysis of 20 business incubation models developed by researchers, consultants and practitioners. He assessed their applicability, performance and efficiency for business innovation. He defines a business incubator as a system that is made up of tools, practices and elements, which increases the chance of entrepreneurs to grow their businesses to mature businesses. What 'elements' constitute of and what is meant by a 'mature business' are also unclear. The aim of his study was to develop a 'virtual incubation' taking into consideration the existing physical business incubators' foundations. Key outcomes listed by him were (1) that business incubators are a support and enabling system for the entrepreneur; and (2) they have main stakeholders and sponsors, who shape their future. The value-add of Ryzhonkov's (2013) study is five key value-adding activities for the entrepreneur that have been identified to: (1) increase the success rate of the new venture; (2) provide an opportunity for the new venture to build trust and credibility in the market; (3) shorten the learning curve; (4) increase the troubleshooting response rate; and (5) access to business networks and strategic alliances. It was also highlighted that business incubation success was positively related to selection performance, frequent monitoring of business assistance efforts, resources and the management and leadership capacity of the business incubator head. Ryzhonkov (2013) also laid responsibility on business incubators by clearly stating that they should be profit-driven, be a learning organisation, measuring itself in terms of the impact they make on communities and on their stakeholders. Business incubators must act as mediators between government, industry and universities to align strategic projects that would benefit the industry, society and the needs of the country. His analysis and critique of the 20 models concluded that most models emphasise the importance of the selection of the incubatees; however, none provide guidelines as to how to select; no performance measures for the incubator itself are set or elaborated on; and few, if any, of the incubation models describe process in detail. In other words, most models are of high level pitched with a clear lack of clarity on the 'how'.

Charry, Perez and Barahona (2014) analysed 50 business incubation articles published between 1985 and 2012 in the field of entrepreneurship. They concluded that various terms are used for business incubators such as Business Accelerators (Barrow 2001), Innovation Centres (Campell 1989) and Knowledge Parks (Bugliarello 1998), and that the nature of incubators has changed: firstly, it was an organisational environment, but after the 2000s it became an instrument of national economic importance.

Scillitoe and Chakrabarti (2010) concluded that there is no common notion that exists, and that business incubation studies are less sophisticated in sampling frames, hypothesis development and dynamic longitudinal analysis.

They argued that it is possible to recognise: (1) the development of business incubators, (2) configuration and the (3) impact business incubators make on the four levels of analysis (individual, organisation, network and the community). 
It can be argued here, from the above literature, that the impact business incubators make on economics country level is important. Thus, adding a fifth level of analysis. The authors of this article argue that complementary models of business incubators can be designed, portraying them as competitors who are attempting to attract tenant firms to co-locate in them. It is also argued that there are business incubators in the same regions and areas who do have similarities and differences. Thus, business incubators can be analysed from different perspectives and at different levels, based on the services they provide to prospective businesses.

Allahar and Brathwalte's (2016) study confirmed the findings of the World Bank report (2013) that developing countries lack affordable infrastructure, mentors and business coaches, training opportunities, finance, business angles, seed capital, a good policy and regulatory system and connections with marketing channels. They identified the key aspects of a good business incubator as entrepreneurs and enterprises at the centre of the incubator; investing in research and development; stimulating entrepreneurship, innovationand creativity at tertiary level; methods to make finance and risk capital more accessible; and simplify tax and regulatory environment.

Up to recently, the types of incubators were more physical incubators. Physical incubators provide facilities and face-toface support at no cost or they are subsidised by government or major corporations. More and more authors refer to virtual incubators (Allahar \& Brathwalte 2016; Ryzhonkov 2013) or mixed business incubators. Nowak and Grantham (2000:131) conducted a study in the software industry in California, USA. They argued for a virtual incubator, based on the fact that it has no physical presence, but a connection to a virtual world made of information (best practices; industry and management experience; resources to market their products globally, increase sales and distribution channels) that will assist the entrepreneur. Janse van Rensburg, Hewitt and Bussin (2018) reported a longitudinal study they conducted to extract engagement factors of 37 entrepreneurs in a 13-week entrepreneurial virtual business coaching programme. An important outcome of this study indicated that it is important to monitor engagement or disengagement within the entrepreneurial virtual business coaching online learning environment. Controllable intrinsic engagement factors that impacted on the entrepreneur's engagement included: fear of selling; mindset of the entrepreneur; language used by the virtual coach; assumptions made by the coach; and the nature of tasks given by the coach to the entrepreneur. It is argued here by the authors that it supports Hewitt and Janse Van Rensburg's (2018) Rensburg view that the ability of the entrepreneur to deal with complexity will impact business growth.

The European Business and Innovation Centre Network (EBN) is a network of 150 business and innovation centres and 70 other organisations that actively support the development and growth of start-ups and SMEs in an effective and efficient way. European Business and Innovation Centre Network released their 2019 impact report, stating the number of entrepreneurs (23 400) they have assisted as well as the number of employment (22 600) they have created.

Specific successes as seen by EBN are funding that has been raised and the respective spending on start-ups (45\%), SMEs and large companies (23\%) and scale-up companies $(16 \%)$. Key services that enabled the enterprises were access to markets $(84 \%)$, finance $(83 \%)$, marketing $(73 \%)$, innovation programmes $(68 \%)$ and team development (65\%). The survival rate of enterprises three years after they have exited the incubator is $89 \%$. The European Business and Innovation Centre Network attribute the survival rate success to the personal commitment and know-how of their professional staff and experts.

\section{Evolution of South Africa's business incubator industry}

Masutha and Rodgerson (2014) provide a very comprehensive, detailed overview of the origin and history of the development and evolution of the business incubator industry in SA. It is not the focus of this article; however, a brief summary will be provided on how events unfolded in SA. The authors observed significant differences between the state-supported incubators versus the private sector-operated incubators. Their study explored more than 10 years of annual reports on SA business incubators. They also conducted interviews with key stakeholders and policy-makers within the business incubation environment as well as with entrepreneurs operating within business incubators. The evolution of business incubators in SA is presented by the authors in four stages. First stage started in 1988 when business hives on the outskirts of townships (Soweto) were established specifically for black entrepreneurs. Business space and collective services in terms of bookkeeping, telecommunications and storage facilities were provided. The hives also served as linkage to larger enterprises. What lacked was the incubation rule period (minimum of a year) as SMEs were not forced out. The second stage in the evolution came about in 2000 with the establishment of the GODISA programme (DTI, Department of Science and Technology [DST] and the European Union [UE]).

Objectives were set to target the rise in SA's challenge of unemployment, inequality and poverty. The aim was to provide services such as training, consulting, business advice and other services for efficient and effective functioning of the incubators housed in them. Technology-focussed SMEs were targeted with economic transformation and to force Black Economic Empowerment (BEE). A national business incubation framework was to be developed. Third stage of evolution came in 2006 when the GODISA Programme was merged to form the SEDA Technology Programme (STP). The aim here was to put in place strategic government support, reduce poverty and increase employment. The fourth stage of the incubation industry is marked by the Incubation Support Programme (ISP) 2012, initiated by the DTI, a plan to be 
rolled out till 2022. The DTI announced plans (2012) to establish 250 business incubators in SA by 2015.

The above authors' studies further revealed that incubatees they interview had an established business before joining the business incubator. The access to infrastructure, the advisory services and access to markets were benefits listed and reasons why they joined the business incubators. However, some frustration was expressed with business advisors (or the lack thereof) and the lack of sharing, transferring good basic business principles, as well as access to finance to expand their businesses. No networking or networking skills between incubatees took place or were provided to incubatees. Some might have employed one additional person. Thus, no or limited growth was experienced. Because of the efforts of the SA government to force BEE-EE, incubatees are mainly black and mostly men, with limited number of females. A study conducted by Hewitt (2009) amongst entrepreneurs mainly in the Gauteng province in SA discussed the impact of trust and trust agents on SMEs' ability to derive benefits from networks as networks are associated positively with business survival and growth. Business trust levels must be built up over time, and it was noted that trust levels amongst black African male and females as well as white females were low compared with trust levels between white males and Asian males. It can be postulated here that little or no networking, lack of trust and the value of partnerships might impair black SME growth.

\section{What is the current state of business incubators in South Africa?}

Van der Spuy (2019) used a qualitative research approached to report on the state of business incubators in the Northern Cape, SA. He argues that the purpose of business incubators is to assist emerging, promising or struggling SMEs to become viable and sustainable businesses after they exist in an incubator. He argues that business incubators must deliver 'full services' and list five categories: (1) physical workspace, (2) administrative support, (3) training and skills development, (4) access to professional skills and finance and (5) access to networks.

Masutha and Rogerson (2014) reported on the evolvement and policy development of business incubators in SA. In SA, the DTI (2014:5) affirms the need for business incubators as a 'cornerstone of industrial development and inclusion in the economy'. The DTI defines a business incubator as a physical or virtual facility that supports the development of early stage SMEs by providing them with business development service, funding and access to physical space to conduct their business in and a focus on development so that they can grow their own capacity as incubation is temporary.

The failure rate is attributed to failure of business strategy and access to funds (SA Incubator Handbook 2015). The lack of funding is one of the most consistent reasons provided by government agencies and start-up entrepreneurs to defend their failure rate or the lack of business growth.
The SA Incubator Handbook (2015: 17) reports that SA's business incubators are spread over the nine provinces: Gauteng accounts for 35; Kwazulu-Natal for 16; Western Cape for 15; Eastern Cape 12; Mpumalanga 10; Limpopo 5; Northern Cape 5; Free State 4; and North-West 3. The Small Enterprise Development Agency is an agency of the Department of Small Business Development that accounts for 42, business incubators in partnership with the DTI and private sector account for 38 and private incubators without state funding account for 25 . This amounts to 105 business incubators, which is less than the anticipated 250 incubators for 2015. However, the latest SEDA available annual report (2017/2018:15) states that their (SEDA) number has increased to 64 incubators. Bayen (2018) puts the number of business incubators in Africa at 442 and in SA at 59. It seems that one institution quotes another without trying to determine what the actual state is. A further desktop study could not verify or confirm any numbers of any of the institutions with each other.

The DTI's ISP wants to attract role players to the incubator industry by offering lucrative and attractive incentives to them. They provide an annual funding of $\mathrm{R} 10 \mathrm{~m}$ for 3 years for incubators in partnership with the private sector or the expansion of existing incubators; SEDA Technology Programme receives funding and provides training to assist SMEs. The Small Enterprise Finance Agency (SEFA) provides direct loans as well as facilities to SMEs.

Other funds are listed such as the National Empowerment Fund (focus on black-owned SMEs) and Black Business Supplier Programme (51\% black ownership). Key performance indicators for business incubators are suggested by the DTI when monitoring and evaluating business incubator performance such as the number of applicants to incubator (target market is aware of incubator); the number of entrepreneurs supported by the incubator (indicates impact of support in terms of scale and if incubator is operating below or above capacity); SME survival rate during incubation (effectiveness of incubator compared with those who have not received incubation); client satisfaction (SME client feedback); SME satisfaction (indicates if incubator serves the needs of SME); and incubators' profitability (sustainability of the incubator) (SA Incubator Handbook 2015).

The SME South Africa Forum (2019) conducted interviews with Andrew Simelani, entrepreneur and managing director of Black Nation Video Network; a venture capitalist, Abu Bakr Cassim, who is the Founder of Ground Flr and Jozi Angels; and a representative from an incubator, Kendal Makgamathe, who is head of Marketing at Tshimologong Digital Innovation Precinct.

Simelani is quoted saying that incubators are heading in the right direction, but that SA is not there yet; he strongly supports the notion that business incubators must be run by experienced entrepreneurs, even those who failed, rather than be driven by inexperienced business academics. He sadly commented on business incubators shutting down as they were fully dependent on donor funding. This is evident that the leaders of business incubators do not know how to 
create and grow a sustainable business for themselves, a matter of the 'blind leading the blind'. He further noticed that some entrepreneurs expect business incubators to run their businesses for them and fail to take up responsibility for the running of their businesses.

Cassim acknowledged that the quality of start-ups is improving and wants to encourage investors; he warns, however, that some business incubators are becoming glorified Internet cafes and create a harbour for SMEs who want to stay dependent and who refuse to grow.

Makgamathe criticised some local business incubators, who are in it for obtaining skills funding and, as they do not have the bigger picture in mind, the quality of SMEs they produce is poor. In the end they marginalise themselves. His advice to upcoming entrepreneurs is to view their customers as their main funders.

\section{Analysis of list of $\mathbf{5 8}$ business incubators}

A definite list of SA business incubators has been released (Crampton 2019), with a total of 58 incubators.

The list provides the focus of each incubator and the expected selected criteria incubatees must adhere to.

Some of the incubators allowed direct access to their websites for further information, and some did not. This complicated the analysis, comparisons and review of the business incubators. Most business incubators list their services in bullet format, thus assuming prospective entrepreneurs will know what they offer and what is expected of them. The business incubators focus on BBB-EE and most are clear that they only accept black Africans, thus excluding other races from participating. Business incubators' target markets ranged from a focus on start-ups, assisting businesses, to grow to the next level, or just any business that wants to apply.

Services ranged from renting out their facilities; access to networks at a subsidised cost; training programmes at a cost to SMEs; and business advisor and coaching opportunities. Incubatees' selection criteria are clearly specified. In some cases, the business incubators were clear about the maximum time period of assistance that would be provided to the incubatees. Business incubators were also clear on their area of specialisation. However, business incubators focussing on training were not specific with their selection criteria. Some business incubators were clear that their focus was on start-ups and taking businesses to the next level. What is meant by next level is 'unclear'.

Visiting the business incubators' websites reveals services they will provide and to whom. However, what lacks is clear guidelines of what their responsibility and undertaking is and what the role and responsibility must be of the incubatee. This lack of upfront information might lead to difficulty, when the incubatee needs to decide to apply or not. Physical visits are also not extended to prospective incubatees to help them to decide if this is the business incubator for them or not. No past successes are claimed. The impression is created that the business incubators view themselves in a position of strength and therefore do not engage in a true partnership with the incubatee.

\section{Analysis of physical visit to three business incubators}

The authors of this article conducted a physical visit to three well-known incubators in Gauteng. It was found that incubator one (private or government and various donors) housed many small- to mid-scale entrepreneurs and could provide a record and history of existing incubatees who expressed their satisfaction with the support they receive; however, some had been there for an extended period with no indication that they want to leave. The business incubator also made it very clear that, although not explicitly mentioned, they only support black entrepreneurs and do not provide opportunities for white entrepreneurs.

Incubator two (corporate funding) was what venture capitalist Abu Bakr Cassim (founder of Ground Flr and Jozi Angels) would refer to as a glorified internet café. The authors consider it as a non-value-add to upskill start-up entrepreneurs or existing entrepreneurs, other than a window-dressing opportunity for the corporate funder.

Incubator three was funded internationally and aimed to make a difference on a community level with community goods or goods from the African continent exported to various countries. A state-of-the-art appearance was maintained, and it was headed by an experienced businessperson. Apart from providing physical space, the incubator assisted with branding, marketing and access to markets. They provided a vibrant and attractive atmosphere to showcase their incubatees' businesses. Active business advice as well as infrastructure support was provided. The focus here was only on BBB-EE candidates.

\section{Conclusion}

Entrepreneurial leaders are considered as entrepreneurs who can contextualise their environment, recognise business opportunities and who are able to attract resources and skills in an innovative manner to take their business to the highest (global) level. Hewitt and Janse Van Rensburg (2017) presented their ELLAC model, clearly dividing the growth of a start-up entrepreneur into seven levels and three business phases: level 1 being the start-up and level 7 the ultimate entrepreneurial leader who operates on a global level.

Most businesses do not pass past level 3 because of their inability to deal with associated business complexities. It is in phase 1, level 1, 2 or 3, where experienced business coaches, 
mentors and resources such as facilities, networks, access to markets and business education (that incubators can provide), can make a difference, if they know how.

The conflicting statements on the state of SMEs in SA are a matter of concern and if national strategic resources are used to drive and uplift SMEs as a catalyst to fight unemployment and poverty, then accurate and reliable data on the state of SMEs need to be gathered and presented. Reading through annual government reports and press releases, the role and benefits of business incubators seem to be presented as positive by the drivers of business incubators. However, bearing in mind the funding, effort and good intentions that went into business incubators, it is clear from SME statistics and unemployment figures that the value-add and role of business incubators can play and should play in SA are not reaching its intended potential as planned.

Longitudinal studies are not available to really determine the success of incubated SMEs after they leave the business incubator. Business incubator success can be placed at their ability to offer value-add, networking opportunities, access to markets and financial risk management. Incubatees want incubators to develop their business know-how, by providing experienced, knowledgeable business coaches and mentors, to act as true business partners.

A study by Zhao, Hills and Seibert (2005) found that entrepreneurs who develop their entrepreneurial education, after they started a business, resulted in higher levels of entrepreneur self-efficacy, thus stressing again the value-add and the role that the business incubators can play in uplifting and stimulating the growth of SMEs. The forced drive to implement BBB-EE and to exclude other races from (especially government-funded) incubators might not be beneficial to immediate communities, the economy and the promotion of building trust, exchanging and learning from each other to build a better SA.

Business incubators need to be able to conceptualise and present their own business model to ensure their own sustainability and also need to be held accountable if they have received state-funding, but they have nothing to show after a few years in operations. More focus should be placed on stimulating SME growth beyond the employee of one additional employee. The role and place of virtual business incubators should be strengthened as SA needs to reach more SMEs across SA. Thus, the role of virtual business coaches and mentors becomes more important.

The one-size-fits-all approach of some business incubators must be avoided. Prospective incubatees must educate themselves to choose a business incubator that can best serve their needs, such as asking the vital questions as proposed by Campell et al. (1985): is this a good business? Does the incubator have the resources and knowledge to support my business and do they know what is the best marketing penetration approach for my business to enter the market? What are the business incubator's success stories?

\section{Future research}

Future research can focus on the perceived relationship of business incubators and business incubatees and the moderating effect of the psychological contract. The question is: who is doing whom a favour here? The role of virtual business incubators, coaches and mentors, considering developments and opportunities the fourth industrial revolution are offering to entrepreneurs (new and existing), should be explored.

\section{Limitations of the research}

The research does not come without its limitations; however, the researchers attempted to apply a non-biased judgement when searching through the vast amount of literature available on the topic at hand. The aim was to report on the important role of business incubators given the unique business context in SA.

\section{Acknowledgements Competing interests}

The authors have declared that no competing interest exists.

\section{Authors' contributions}

All authors contributed equally to this work.

\section{Funding information}

This research received no specific grant from any funding agency in the public, commercial or not-forprofit sectors.

\section{Ethical consideration}

This article followed all ethical standards for a research without direct contact with human or animal subjects.

\section{Data availability statement}

Data sharing is not applicable to this article as no new data were created or analysed in this study.

\section{Disclaimer}

The views and opinions expressed in this article are those of the authors and do not necessarily reflect the official policy or position of any affiliated agency of the authors.

\section{References}

Allahar, H. \& Brathwalte, C., 2016, 'Business incubation as an instrument of innovation: The experience of South America and the Carribean', International Journal of Innovation 4(2), 71-85. https://doi.org/10.5585/iji.v4i2.107

Barrow, C., 2001, In incubators: A realist's guide to the world's new business accelerators, pp. 13-36, John Wiley, Chichester. 
Bayen, M., 2018, Africa: A look at the 442 active tech hubs of the continent, viewed 02 July 2020, from https://www.gsma.com/mobilefordevelopment/blog-2/africa-alook-at-the-442-active-tech-hubs-of-the-continent/.

Bugliarello, G., 1998, 'Knowledge parks and incubators', The Handbook of Technology Management 1, 41-49.

Charry, G.P., Perez, J.E.A. \& Barahona, N.E.L., 2014, Business incubation research: A review and future research, pp. 41-65, Pensamiento \& Gestion, 3, Universidad del Norte, Barranquilla-Colombia.

Campbell, C., 1984, Hatching small businesses: Planning, National Business Incubation Association, Chicago, IL.

Campell, C., Kendrick, R.C. \& Samuelson, D.S., 1985, 'Stalking the latent entrepreneur: Business incubators and economic development', Economic Development Review 2(2), 43-49.

Crampton, N., 2019, The definite list of South African Incubators for start-ups, viewed 01 July 2019, from https://www.entrepreneur.com/article/327566.

Department of Trade and Industry (DTI), 2014, South Africa Business Incubator establishment handbook: A guide to establishing business incubators in South Africa, viewed 01 July 2019, from http://www.innovationeasterncape.co.za/wpcontent/uploads/2016/05/sa_incubator_handbook.pdf.

Fotoyi, A. \& Levin, S., 2019, 'Special edition: The state of small business in South Africa', in N. Ndlovu \& M. Makgetla (eds.), The real economy Bulletin: Trends, developments and data, viewed 30 June 2020, from https://www.tips.org.za/ images/Real_Economy_Bulletin_Small_Business_Edition_January_2019.pdf.

Fotoyi, A. \& Levin, S., 2019, The state of small business in South Africa, N. Ndlovu \& M. Makgetla (eds.), The Real Economy Bulletin, Special Edition, viewed 02 July 2020 from https://www.tips.org.za/manufacturing-data/the-real-economy-bulletin/ the-state-of-small-business-in-south-africa/item/3557-reb-special-edition-thestate-of-small-business-in-south-africa\%20_Edition_January_2017\%20(1).pdf.

Gray, D.E., 2014, Doing research in the real world, 3rd edn., Sage, Washington, DC.

Hackett, S.M. \& Dilts, D., 2004, 'A systematic review of Business Incubation research', The Journal of Technology Transfer 29, 55-82. https://doi.org/10.1023/B: The Journal of Technol

Hausberg, P.J. \& Korreck, S., 2018, 'Business incubators and accelerators: A co-citation analysis-based, systematic literature review', Journal of Technology Transfer 45, 151-176. https://doi.org/10.1007/s10961-018-9651

Hewitt, M. \& Janse van Rensburg, L., 2017, 'From Start-Up Entrepreneur to Entrepreneurial Leader - A conceptual Model', viewed n.d., from https://ujcontent. uj.ac.za/vital/access/manager/Repository/uj:25279?site_name=GlobalView

Hewitt, L.M.M., 2009, Confirming influencing factors on small medium enterprise (SMEs) activity, pp. 80-104, The Research and Knowledge Management Division SEDA, Pretoria.

Janse Van Rensburg, L.J., Hewitt, L.M.M. \& Bussin, M., 2018, 'Engagement factors that contribute to entrepreneurial virtual coaching success', in Published in the proceeding of the 2nd Business \& Entrepreneurial Economics Conference, Brijuni, Croatia, May 24-26.

Leshou, C., 2019, We aim to improve SMME sector, viewed 02 July 2020, from https:// www.engineeringnews.co.za/article/number-of-south-african-smmeswww.engineering
growing-2017-06-26/

Lewis, D.A., 2001, Does technology incubation work: A critical review of the evidence, US Department of Commerce Economic Development Administration, Washington, DC.

Makgetla, N., Philip, K. \& Fotoyi, A., 2019, 'The state of small business in South Africa', The Real Economy Bulletin, Special edn., viewed 02 July 2020, from https://www.tips.org.za/ images/Real_Economy_Bulletin_Small_Business_Edition_January_2019.pdf.

Makgetla, N., Philip, K. \& Fotoyi, A., 2019, The state of small business in South Africa S. Levin (ed.), The Real Economy Bulletin, Special Edition, viewed 30 June 2020 from https://www.tips.org.za/manufacturing-data/the-real-economy-bulletin/ the-state-of-small-business-in-south-africa/item/3557-reb-special-edition-thestate-of-small-business-in-south-africa\%20_Edition_January_2019\%20(1).pdf.
Masutha, M. \& Rogerson, C.M., 2014, 'Small enterprise development in South Africa: The role of business incubators', in C.M. Rogerson \& D. Szymańska (eds.), Bulletin of geography, Socio-economic series, no. 26, pp. 141-155, (eds.), Bulletin of geography, Socio-economic series, no. 26, pp. 141-155,
Nicolaus Copernicus University, Toruń. https://doi.org/10.2478/bog-20140050

Merrifield, B.D., 1987, 'New business incubators', Journal of Business Venturing 2(4), 277-284. https://doi.org/10.1016/0883-9026(87)90021-8

Nowak, J.M. \& Grantham, C.E., 2000, 'The virtual incubator: Managing human capital in the software industry', Research Policy 29, 129-134. https://doi.org/10.1016/ S0048-7333(99)00054-2

Rathore, R.S. \& Agrawal, R., 2020, Measuring performance of business incubators: $A$ literature review and theoretical framework development, viewed n.d., from https://ssrn.com/abstract=3573354.

Ryzhonkov, A., 2013, 'Analysis of 20 incubation models', viewed 01 July, from https:// worldbusinessincubation.wordpress.com/2013/11/28/907/.

Saba, A., 2018, Has BEE been a dismal failure?, viewed 30 June 2019, from https:// mg.co.za/article/2018-08-31-00-has-bee-been-a-dismal-failure.

Scillitoe, L.L. \& Chakrabarti, A.K., 2010, 'The role of incubator interaction in assisting new ventures', Technovation 30(3), 155-167. https://doi.org/10.1016/j. technovation.2009.12.002

Small Business Institute, 2018, The number of formal micro, small \& medium businesses in South Africa, viewed 28 June 2019, from https://www.smallbusinessinstitute. co.za/wp-content/uploads/2019/01/SBIbaselineStudyAlertfinal.pdf.

Small Enterprise Development Agency (SEDA), 2017, SMME Quarterly update: 3rd Quarter 2017, viewed 02 July 2020, from http://www.seda.org.za/Publications/ Publications/SMME\%20Quarterly\%202017-Q3.pdf.

Small Enterprise Development Agency (SEDA), 2018, SMME quarterly update: 3rd quarter, viewed 02 July 2020, from http://www.seda.org.za/Publications/ Publications/SMME\%20Quarterly,\%202018-Q3.pdf.

Smilor, R.W., 1987, 'Managing the incubator system: Critical success factors to accelerate new company development', IEEE Transactions on Engineering Management 34(3), 146-155. https://doi.org/10.1109/TEM.1987.6498875

South Africa Business Incubator Establishment Handbook, 2014, A guide to establishing business incubators in South Africa, viewed 01 July 2019, from http:// www.innovationeasterncape.co.za/wp- content/uploads/2016/05/sa_incubator_ handbook.pdf.

South African Market Insights, 2019, 'South Africa's GDP per capita will be less than emerging markets soon', viewed 30 June 2019, from https://www.southafricanmi. com/sa-vs-the-world.html.

Statistics South Africa, 2019, Quarterly financial statistics, viewed 16 April 2020 from http://www.statssa.gov.za/publications/P0044/P0044March2019.pdf.

Van der Spuy, J.H., 2019, 'The state of business incubation in the Northern Cape: A service spectrum perspective', The Southern African Journal of Entrepreneurship and Small Business Management 11(1), a271. https://doi.org/10.4102/sajesbm. v11i1.271

The Department of Small Business, 2018/2019, Annual performance plan, viewed 02 July 2019, from https://pmg.org.za/committee-meeting/26261/.

World Bank, 2013, The World Bank Annual Report 2013, viewed n.d., from https:// openknowledge.worldbank.org/handle/10986/16091.

World Bank Report, 2018, Republic of South Africa systematic country diagnostic: An incomplete transition: Overcoming the legacy of exclusion in South Africa, viewed 02 July 2020, from http://documents1.worldbank.org/curated/ en/815401525706928690/pdf/WBG-South-Africa-Systematic-CountryDiagnostic-FINAL-for-board-SECPO-Edit-05032018.pdf.

Zhao, H., Hills, G.E. \& Seibert, S.E., 2005, 'The mediating role of self-efficacy in the development of entrepreneurial intentions', Journal of Applied Psychology 90(6), 1265-1272. https://doi.org/10.1037/0021-9010.90.6.1265 